\title{
ARTICLE
}

\section{Catch composition of deep-sea resources of commercial importance in the Colombian Caribbean}

Composición de las capturas de los recursos de aguas profundas de importancia comercial en el Caribe colombiano

\section{Marcela Grijalba-Bendeck ${ }^{1}$, Jorge Paramo ${ }^{2 *}$ and Matthias Wolff ${ }^{3}$}

\author{
'Programa de Biología Marina, Grupo de Investigación Dinámica y Manejo de Ecosistemas Marino-Costeros (DIMARCO), Facultad de \\ Ciencias Naturales e Ingeniería, Universidad de Bogotá Jorge Tadeo Lozano, Carrera 2 No. 11-68, Edificio Mundo Marino, Rodadero, \\ Santa Marta, Colombia.marcela.grijalba@utadeo.edu.co \\ ${ }^{2}$ Grupo de Investigación Ciencia y Tecnología Pesquera Tropical (CITEPT), Universidad del Magdalena, Carrera 32 No. 22-08, Avenida \\ del Ferrocarril, Santa Marta, Colombia \\ ${ }^{3}$ Leibniz-Zentrum Für Marine Tropenökologie (ZMT), University of Bremen, Fahrenheitstraße 6, 28359, Germany. matthias.wolff@ \\ zmt-bremen.de \\ "Corresponding author: jparamo@unimagdalena.edu.co
}

\begin{abstract}
Resumen.- Recientes estudios en el Caribe colombiano describen el potencial para una nueva pesquería de crustáceos entre 200 a 550 $\mathrm{m}$ de profundidad. Con el fin de soportar planes de manejo apropiados para su utilización sostenible, el objetivo del presente estudio fue identificar la composición de la captura y detectar tendencias generales en la distribución batimétrica de las cuatro principales categorías biológicas (crustáceos, teleósteos, condrictios y moluscos), en relación con el estrato de profundidad. Una captura por unidad de área total de 8.759 ind. $\mathrm{km}^{-2}$ y $226 \mathrm{~kg} \mathrm{~km}^{-2}$ fue reportada y la mayor contribución fue soportada por los peces teleósteos (89 especies; $62 \%$ abundancia y $73 \%$ de biomasa total), dominando el estrato de profundidad de 200-300 m, seguido por los crustáceos (36 y $22 \%$, respectivamente), para aguas más profundas (>500 m). Las especies más importantes fueron los peces Coelorinchus caelorhincus (20,2 ind. $\left.\mathrm{km}^{-2} ; 16,7 \mathrm{~kg} \mathrm{~km}^{-2}\right)$ y los crustáceos Penaeopsis serrata ( 579 ind. $\mathrm{km}^{-2}, 7 \%$ de la abundancia total) y Pleoticus robustus (12,6 kg $\mathrm{km}^{-2}, 6 \%$ de la biomasa total). La información obtenida es parte de la línea de base requerida para describir el potencial efecto de las pesquerías de aguas profundas en el ecosistema y soportan futuras decisiones acerca del uso, manejo y conservación de los recursos de aguas profundas de esta región.
\end{abstract}

Palabras clave: Aguas profundas, pesquería, crustáceos, Colombia, Caribe

\begin{abstract}
Recent studies in the Colombian Caribbean Sea describe the potential for a new deep-sea crustacean fishery between 200 a $550 \mathrm{~m}$ depth. In order to support appropriate management plans for their sustainable utilization, the goal of the present study was to identify the catch composition and to detect general trends in the bathymetric distribution of the main four biological categories (crustaceans, teleostean, chondrichthyes and molluscs), in relation to depth strata. A total catch per unit area of 8,759 ind. $\mathrm{km}^{-2}$ and $226 \mathrm{~kg} \mathrm{~km}^{-2}$ was reported and the major contribution was supported by teleostean fish ( 89 species; $62 \%$ abundance and $73 \%$ of total biomass), dominating the depth stratum 200-300 m, followed by crustaceans ( 36 and 22\%, respectively) for deeper waters (> $500 \mathrm{~m}$ ). Most important species were the fish Coelorinchus caelorhincus (20.2 ind. km-2; $16.7 \mathrm{~kg} \mathrm{~km}^{-2}$ ) and the crustaceans Penaeopsis serrata ( 579 ind. $\mathrm{km}^{-2}, 7 \%$ of the total abundance) and Pleoticus robustus ( $12.6 \mathrm{~kg} \mathrm{~km}^{-2}, 6 \%$ of the total biomass). The information obtained is part of a base line required to describing the potential effects of deep-sea fisheries on the ecosystem and supporting future decisions about use, management and conservation of deep resources for this region.
\end{abstract}

Key words: Deep-sea, fishery, crustaceans, Colombia, Caribbean

\section{INTRODUCTION}

The by-catch is a major concern worldwide, it has been estimated in 7.3 million ton mean per year and most of the contribution is from by-catch landings of shrimp fisheries (27\%) (Kelleher 2005). By-catch and discards are the most important topics in fishery management (Paighambari \& Moslem 2012). Recent studies in the Colombian Caribbean Sea revealed several areas of high concentration of commercially important deep-sea decapod crustaceans (i.e., Aristaeomorpha foliacea, Pleoticus robustus, Penaeopsis serrata, Metanephrops binghami) representing a potential new deep fishery resource (Paramo \& Saint-Paul 2012a,b,c).
These potential fisheries have great economic importance in the emergent development of deep-sea fisheries particularly in Latin America (Arana et al. 2009), where crustaceans, as opposed to fishes, have a noticeable commercial interest (Wehrtmann \& Echeverría 2007, Wehrtmann et al. 2012, Pérez et al. 2013). However, it is well known that deep-sea resources are highly vulnerable to over-exploitation due to their life-history characteristics that include long longevity, slow growth rate, late maturity and low fecundity (Morato et al. 2006, Follesa et al. 2011). Therefore, deep sea stocks are depleted more easily, and recovery will be much slower than for species in shallow waters (Roberts 2002). 
Despite its importance, the deep-sea demersal fauna from the continental margin of the Colombian Caribbean is relatively unknown (Paramo et al. 2012). There is an increasing interest in the exploitation of deep-water (defined here as >200 m; Cavanagh \& Kyne 2006) resources in this area. Available studies from deeper waters of the Colombian Caribbean have focused on length-weight relationships for selected species (Díaz et al. 2000), technical reports for potential commercial fisheries (Álvarez-León \& Rey-Carrasco 2003), species reports (Roa-Varón et al. 2003, Saavedra et al. 2004) and deep fish inventories (Polanco et al. 2010).

Different studies demonstrated that fishing activities could cause significant changes in deep- sea ecosystems (Bianchi et al. 2000, Labropoulou \& Papaconstantinou 2005). Therefore, research about the by-catch associated to commercial species (shrimps) of the Colombian Caribbean Sea is crucial for describing the potential ecosystem effects of these fisheries and for supporting future decisions about policies and strategies for management and conservation of deep resources. Thus, the present study aimed to identify the catch composition and to detect general trends in the bathymetric distribution of the main biological categories (crustaceans, teleostean fish, chondrichthyes and molluscs), in relation to depth strata of a potentially new deep-sea resource in the Colombian Caribbean.

\section{MATERIALS AND METHODS}

\section{STUdY AREA AND SAMPLING DESIGN}

Experimental trawls during two surveys in November and December of 2009 were carried in depths ranging from 200 to $550 \mathrm{~m}$ in the Colombian Caribbean. Samples were collected by the commercial shrimp vessel "Tee Claude" using a trawl with a cod-end mesh size of $44.5 \mathrm{~mm}$ from knot to knot. The actual location of trawlable bottoms were found using a commercial echosounder FURUNO FCV 1150 with a transducer at a frequency of $28 \mathrm{kHz}$, with at least two hauls per $100 \mathrm{~m}$ depth stratum, on a grid of 60 stations (10 sampled stations between 200-300 m depth, 26 between 300-400 m, 18 between 400-500 m, and 6 at depth $>500$ m) (Fig. 1). No samples were collected between Cartagena and Magdalena River due to the irregular depth in this zone. The effective haul duration was $30 \mathrm{~min}$ and the tow distance by the net was estimated by means of a GPS Garmin MAP 76CSx. Total and relative (\%) number and weight of individuals were recorded by categories of crustaceans (commercial and non-commercial), teleostean fish, chondrichthyes and molluscs. The deep-sea catch per unit of area (CPUA) was standardized by $\mathrm{km}^{2}$ of sample area for total abundance (ind. $\mathrm{km}^{-2}$ ) and biomass $\left(\mathrm{kg} \mathrm{km}^{-2}\right)$. The swept area was estimated considering the spread of the net $(11.58 \mathrm{~m})$, using the vulnerability correction factor for shrimp trawls nets (0.7) (Sparre \& Venema 1995) and the speed of the vessel (average 2.5 knots) (Gunderson 1993, King 2007). The catch composition by weight and number was standardized by depth strata; species regarded as pelagic and hard bottom associated were excluded from the analysis (D’Onghia et al. 2004).

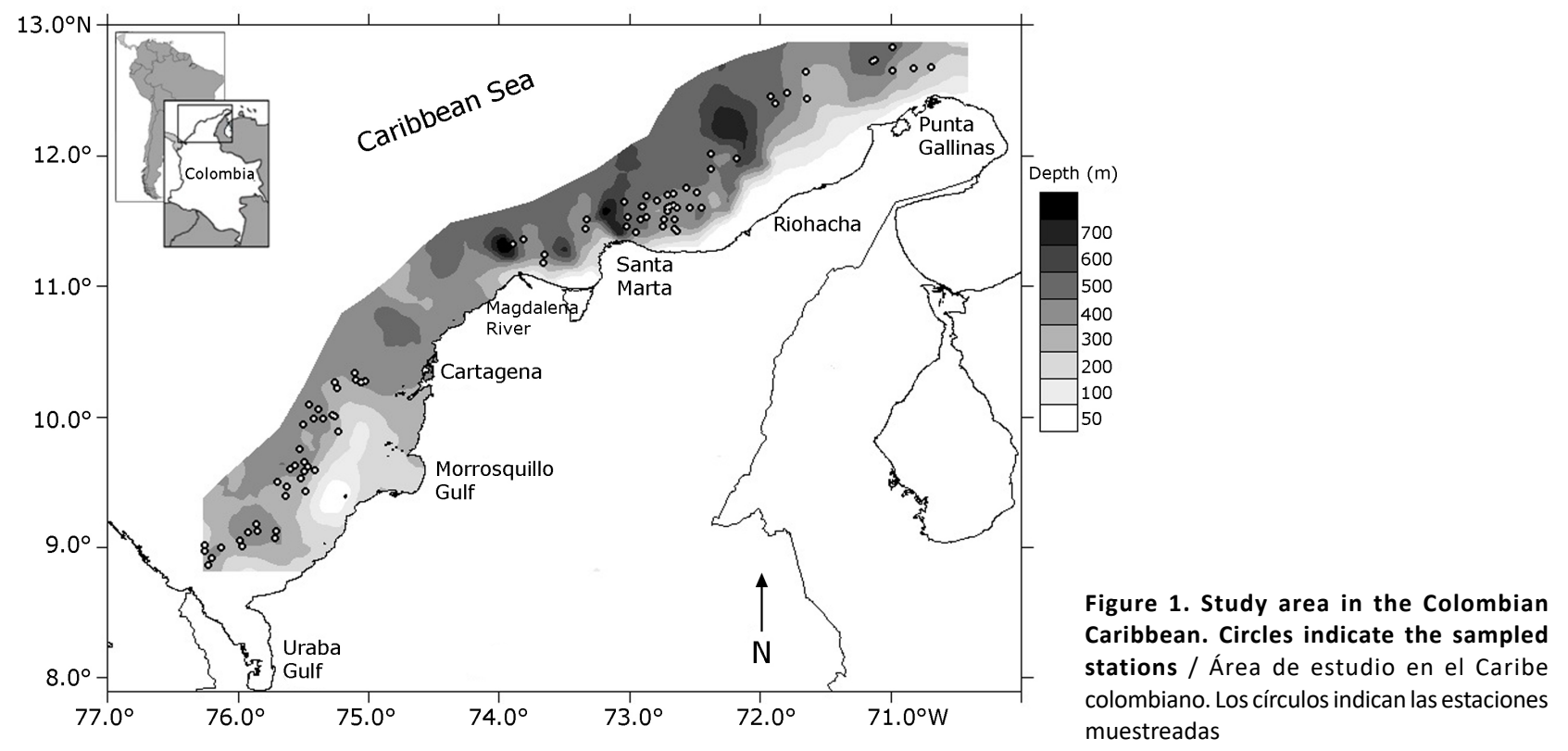




\section{STATISTICAL ANALYSIS}

The quantitative species composition for each $100 \mathrm{~m}$ stratum intervals was analyzed. In each interval the dominant species in terms of both abundance and biomass were determined. Due to the substantial marketability of four deep-sea crustaceans (Aristaeomorpha foliacea, Pleoticus robustus, Penaeopsis serrata, Metanephrops binghami) make them as a potential new economic resource in the Colombian Caribbean (Paramo \& Saint-Paul 2012a,b,c), were labeled as commercial crustaceans (CC). Non-commercial crustacean species were named as NoCC and teleostean fish, chondrichthyans and molluscs, as total by-catch. The calculated indices from the biomass and abundance trawl data were 1) the ratio of by-catch to $\mathrm{CC}, 2$ ) the ratio of chondrichthyans to $\mathrm{CC}, 3$ ) the ratio of chondrichthyans to total catch (TC), 4) the ratio of teleosteans to $\mathrm{CC}$ and $5)$ the ratio of NonCC to CC. Changes with depth in the calculated indices were evaluated using Generalized Additive Models (GAM) (Hastie \& Tibshirani 1990). The analysis was exploratory with the aim to describe the bathymetric distribution of the above-mentioned indexes. An additive model is an extension of a linear model, but allows linear functions of predictors (depth) to be replaced by smoothing functions (Agenbag et al. 2003), as follows:

$$
y=\alpha+\sum_{i=1}^{n} \cdot f i(X i)+\varepsilon
$$

where, $y$ is the response, $X i$ the predictor, $\alpha$ a constant and $\varepsilon$ the error term. The function $f$ is estimated using smoothers. We used spline (s) smoothing with a Gaussian model (Burnham \& Anderson 2002). Differences in CPUA values of abundance and biomass between depth stratum from crustacean, teleostean fish, chondrichthyes and molluscs, were evaluated using Kruskal-Wallis non-parametric test (Gotelli \& Ellison 2004, Zar 2009).

\section{Results}

A total CPUA of 8,759 ind. $\mathrm{km}^{-2}$ and $226 \mathrm{~kg} \mathrm{~km}^{-2}$ were obtained for all sampled stations. Highest abundance (ind. $\mathrm{km}^{-2}$ ) was represented by teleostean fish from the total calculated, followed by the crustaceans, chondrichthyes and molluscs. Fish and crustaceans accounted for most of the total catch in biomass $\left(\mathrm{kg} \mathrm{km}^{-2}\right)$, followed by chondrichthyes and molluses (Fig. 2).

Higher abundance and biomass for crustaceans were obtained for $>500 \mathrm{~m}$ stratum. Highest fish abundances occurred in the 200-300 m depth stratum and most of the fish biomass was collected in depths $>500 \mathrm{~m}$. Between the fish category, deep-sea teleosteans represented most part of the total catch in terms of abundance and biomass. The fish abundance decreased with the increase in depth. However, the crustacean abundance increased with depth (Fig. 3). Nevertheless, a comparison of the CPUA in abundance and biomass using Kruskal-Wallis non-parametric test, showed no statistical differences $(P>0.05)$ in abundance and neither biomass between depth strata by group category.

Teleostean fish captures were represented by 48 teleostean families and 89 species, the orders Gadiformes (33 species), Perciformes (16 species), Zeiformes (7 species) and Scorpaeniformes (6 species), amounted to almost 62 species of the fish species inhabiting the deeper waters of the Colombian Caribbean. The families Macrouridae, Zeniontidae, Merluciidae, Trachichthyidae,

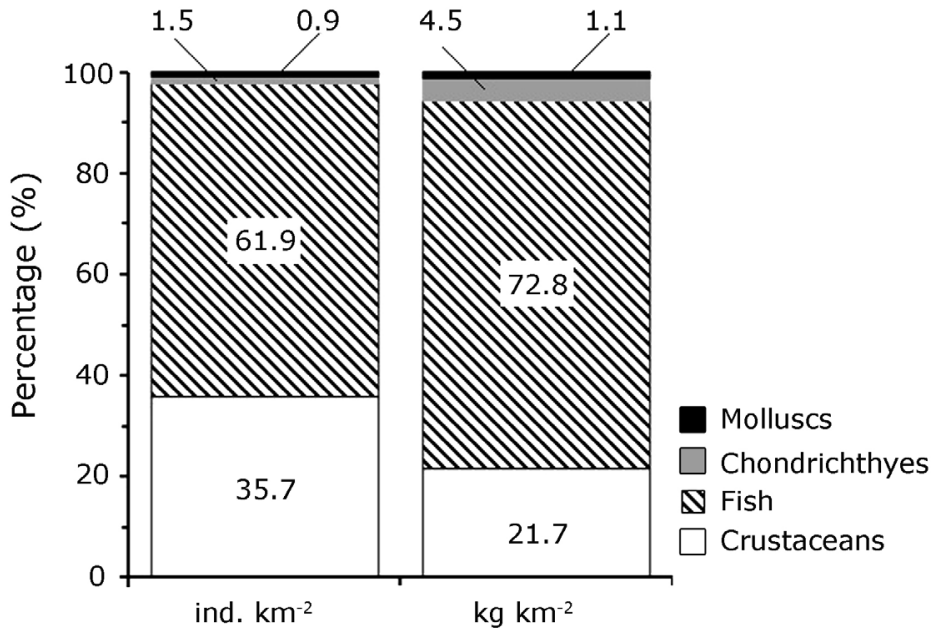

Figure 2. Abundance in terms of number (ind. $\mathbf{k m}^{-2}$ ) and weight $\left(\mathrm{kg} \mathrm{km}^{-2}\right)$ of the four main categories of the catch of deep-sea Colombian Caribbean / Abundancia en términos de número (ind. $\left.\mathrm{km}^{-2}\right)$ y peso $\left(\mathrm{kg} \mathrm{km}^{-2}\right)$ de las cuatro categorías principales de la captura de aguas profundas en el Caribe colombiano 
a)

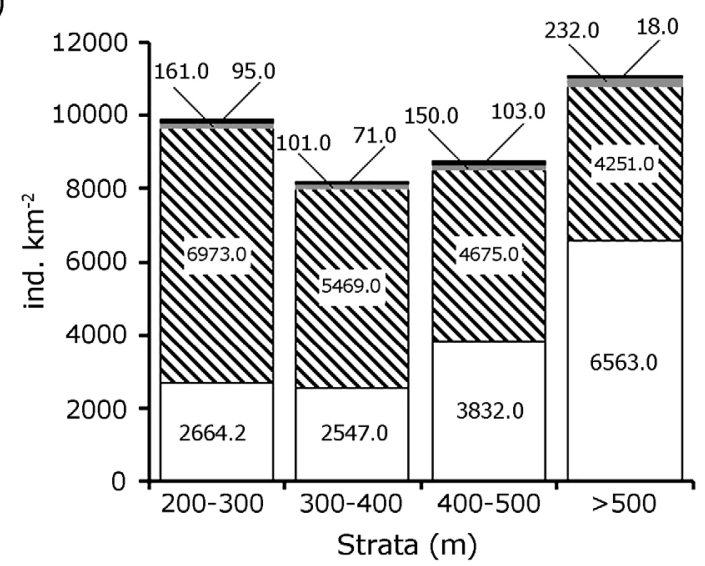

b)

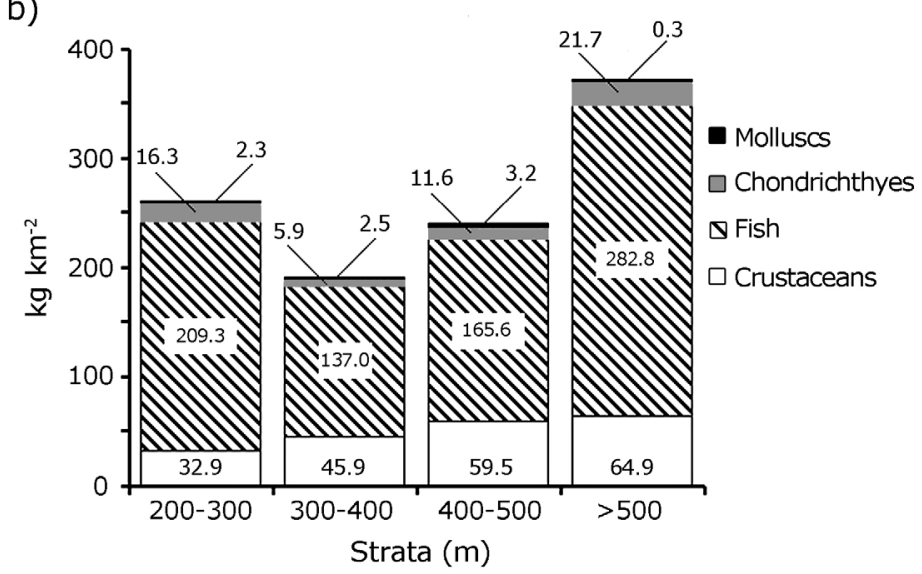

Figure 3. Deep-sea catch composition in terms of: a) abundance (ind. $\mathbf{k m}^{-2}$ ), b) biomass ( $\mathbf{k g ~ k m}^{-2}$ ) by depth stratum (m) in the Colombian Caribbean / Composición de la captura de aguas profundas en términos de: a) abundancia (ind. $\mathrm{km}^{-2}$ ), b) biomasa ( $\mathrm{kg} \mathrm{km}{ }^{-2}$ ) por estrato de profundidad ( $\mathrm{m}$ ) en el Caribe colombiano

Chlorophthalmidae, Setarchidae and Epigonidae, accounted $55 \%$ of the total fish abundance, including teleosteans and chondrichthyans. The most abundant species were Coelorinchus caelorhincus (20.2 ind. $\mathrm{km}^{-2} ; 16.7 \mathrm{~kg}$ $\mathrm{km}^{-2}$ ), Zenion hololepis (13.4 ind. $\mathrm{km}^{-2} ; 4.1 \mathrm{~kg} \mathrm{~km}^{-2}$ ), Steindachneria argentea (4.5 ind. $\mathrm{km}^{-2} ; 9.4 \mathrm{~kg} \mathrm{~km}^{-2}$ ), Chlorophthalmus agassizi (2.0 ind. $\mathrm{km}^{-2} ; 0.8 \mathrm{~kg} \mathrm{~km}^{-2}$ ), Poecilopsetta beanii (2.4 ind. $\mathrm{km}^{-2} ; 0.6 \mathrm{~kg} \mathrm{~km}^{-2}$ ), Chaunax suttkusi (2.3 ind. $\left.\mathrm{km}^{-2} ; 2.5 \mathrm{~kg} \mathrm{~km}^{-2}\right)$, Neobythites gilli $(2.3$ ind. $\mathrm{km}^{-2} ; 0.7 \mathrm{~kg} \mathrm{~km}^{-2}$ ), Bembrops anatirostris (1.8 ind. $\mathrm{km}^{-2} ; 2.3 \mathrm{~kg} \mathrm{~km}^{-2}$ ), Hymenocephalus sp. (1.3 ind. $\mathrm{km}^{-2} ; 2.7$ $\mathrm{kg} \mathrm{km}^{-2}$ ) and Cyttopsis rosea (1.3 ind. $\mathrm{km}^{-2} ; 0.7 \mathrm{~kg} \mathrm{~km}^{-2}$ ).

Chondrichthyes proportion was always low among strata, ranging between $1.2-2.1 \%$ in abundance and 3.1$6.2 \%$ in biomass. A total of 9 chondrichthyan orders and 13 species occurred in $28 \%$ of the sampled stations. The most abundant chondrichthyan species were Etmopterus perryi (1.1 ind. $\left.\mathrm{km}^{-2} ; 1.0 \mathrm{~kg} \mathrm{~km}^{-2}\right)$, Gurgesiella atlantica (0.2 ind. $\left.\mathrm{km}^{-2} ; 0.6 \mathrm{~kg} \mathrm{~km}^{-2}\right)$, Anacanthobatis americanus (0.2 ind. $\left.\mathrm{km}^{-2} ; 0.6 \mathrm{~kg} \mathrm{~km}^{-2}\right)$, Galeus cadenati $\left(0.2\right.$ ind $\mathrm{km}^{-2} ; 0.5$ $\mathrm{kg} \mathrm{km}^{-2}$ ), Squalus cubensis (0.2 ind. $\left.\mathrm{km}^{-2} ; 0.4 \mathrm{~kg} \mathrm{~km}^{-2}\right)$, Cruriraja rugosa $\left(0.1\right.$ ind. $\left.\mathrm{km}^{-2} ; 0.8 \mathrm{~kg} \mathrm{~km}^{-2}\right)$, Hydrolagus alberti $\left(0.1\right.$ ind. $\left.\mathrm{km}^{-2} ; 0.4 \mathrm{~kg} \mathrm{~km}^{-2}\right)$, Scyliorhinus boa $(0.1$ ind. $\left.\mathrm{km}^{-2} ; 0.4 \mathrm{~kg} \mathrm{~km}^{-2}\right)$, Squatina dumeril (0.04 ind. $\mathrm{km}^{-2}$; $\left.0.8 \mathrm{~kg} \mathrm{~km}^{-2}\right)$, Anacanthobatis sp. (0.03 ind. $\mathrm{km}^{-2} ; 0.04 \mathrm{~kg}$ $\left.\mathrm{km}^{-2}\right)$, Neoharriotta carri (0.02 ind. $\left.\mathrm{km}^{-2} ; 0.10 \mathrm{~kg} \mathrm{~km}^{-2}\right)$, Dactylobatus clarkii (0.01 ind. $\mathrm{km}^{-2} ; 0.23 \mathrm{~kg} \mathrm{~km}^{-2}$ ) and Centrophorus granulosus ( 0.01 ind. $\mathrm{km}^{-2} ; 0.09 \mathrm{~kg} \mathrm{~km}^{-2}$ ). Molluscs constituted $0.2-1.2 \%$ of abundance and $0.1-1.3 \%$ of biomass among all depth strata (Fig. 3).

The most important commercial deep-sea crustacean in terms of individual number was $P$. serrata followed by $P$. robustus, $A$. foliacea and $B$. binghami and for the biomass $P$. robustus followed by $A$. foliacea, $M$. binghami and $P$. serrata (Table 1). Penaeopsis serrata was dominant in terms of abundance between the strata 200-300 m, 300-400 $\mathrm{m}$ and 400-500 m. For depths $>500 \mathrm{~m}$ the highest abundance was registered for $P$. robustus (Table 1). The highest biomass for $P$. robustus was recorded in the stratum $>500 \mathrm{~m}$ and 400 500, followed by Metanephrops binghami in 200-300 m and 300-400 m. Metanephrops binhgami was not captured in the $>500 \mathrm{~m}$ stratum (Table 1 ).

Table 1. Commercial crustacean species catch composition on deepsea grounds in terms of total and relative abundance (ind. $\mathbf{~ m}^{-2}$ ) and biomass $\left(\mathrm{kg} \mathrm{km}^{-2}\right)$. The percentage in parentheses is related to the total of catch per unit area / Composición de la captura de especies de crustáceos comerciales en regiones de aguas profundas en términos de abundancia total y relativa (ind. $\mathrm{km}^{-2}$ ) y biomasa $\left(\mathrm{kg} \mathrm{km}^{-2}\right)$. El porcentaje en paréntesis está relacionado al total de la captura por unidad de área

\begin{tabular}{ccccc}
\hline \multirow{2}{*}{ Strata $(\mathrm{m})$} & \multicolumn{4}{c}{ CPUA (ind. km) } \\
\cline { 2 - 5 } & A. foliacea & P. robustus & P. serrata & M. binghami \\
\hline Total & $355(4.0 \%)$ & $378(4.3 \%)$ & $579(6.6 \%)$ & $223(2.5 \%)$ \\
$200-300$ & $347(3.5 \%)$ & $128(1.2 \%)$ & $354(3.5 \%)$ & $314(3.1 \%)$ \\
$300-400$ & $300(3.6 \%)$ & $184(2.2 \%)$ & $512(6.2 \%)$ & $303(3.6 \%)$ \\
$400-500$ & $396(4.5 \%)$ & $703(8.0 \%)$ & $829(9.4 \%)$ & $107(1.2 \%)$ \\
$>500$ & $616(5.5 \%)$ & $742(6.7 \%)$ & $196(1.7 \%)$ & $0(0 \%)$ \\
\hline \multirow{2}{*}{ Strata $(\mathrm{m})$} & A.foliacea & P. robustus & P. serrata & M. binghami \\
\hline Total & $8.2(3.6 \%)$ & $13.1(5.7 \%)$ & $3.6(1.5 \%)$ & $6.7(2.9 \%)$ \\
$200-300$ & $5.1(1.9 \%)$ & $3.5(1.3 \%)$ & $1.6(0.6 \%)$ & $6.6(2.5 \%)$ \\
$300-400$ & $6.4(3.3 \%)$ & $8.1(4.2 \%)$ & $2.7(1.4 \%)$ & $9.6(5.0 \%)$ \\
$400-500$ & $10.4(4.3 \%)$ & $22.3(9.2 \%)$ & $5.9(2.4 \%)$ & $3.5(1.4 \%)$ \\
$>500$ & $20.9(5.6 \%)$ & $25.7(6.9 \%)$ & $2.0(0.5 \%)$ & $0(0 \%)$ \\
\hline
\end{tabular}


The model fit was significant $(P<0.01)$ in explaining the variability of bathymetric distribution of the calculated indices. Higher ratios of by-catch to CC $(10.1 \%$ of explained deviance) (Fig. 4a), Teleosteans to CC $(6.1 \%$ of explained deviance) (Fig. 4b) and NonCC to CC (23.6\% of explained deviance) (Fig. 4c) were found at shallower depths (200-300 $\mathrm{m})$; the minimum values of these ratios showed a decrease from $350 \mathrm{~m}$ to $550 \mathrm{~m}$. When the chondrichthyes were separated in the analysis, the ratios chondrichthyes to CC (26.5\% of explained deviance) (Fig. 4d) and chondrichthyes to TC (23.9\% of explained deviance) (Fig. 4e) showed a strong increment at shallower depths (270-300 m).

\section{Discussion}

Results of the present study for the total catch from the experimental trawling in the Colombian Caribbean showed that the abundance and biomass of fish catches were 1.7 and 3.3 times higher, respectively, than the crustacean contribution. The following groups were the chondrichthyes and the molluscs, both with a marked less proportion than the former groups. In Turkey (Iskenderun Bay) fish and shellfish represent the $97 \%$ of the landings by weight and $72 \%$ of the captures of economic value (Can et al. 2004). Additionally, the catch composition of the trawl fleet operating from Mallorca (Balearic Islands) reported the major proportion of fish in the total catch, with around $70 \%$ of the discarded biomass for mean depths between 300 and $616 \mathrm{~m}$, resulting in overfishing over some target fish species (Moranta et al. 2000). For the Bushehr coastal waters (Persian Gulf) the $12.5 \%$ of the total catch was represented by target species of shrimp and $87.5 \%$ was by-catch. The reported by-catch for this region includes 114 species from 45 teleostei families (14.0\%), 13 species from 7 elasmobranchs families $(14.0 \%)$ and 13 species from 13 invertebrate families (13.9\%), demonstrating that shrimp trawls produce large catches of fishes, including some demersal threatened species by catching the adults and immature individuals (Paighambari \& Moslem 2012).

Despite differences in sampling designs, it is noticeable that for the present study the stratum $>500 \mathrm{~m}$ contributed to the highest abundance. Same results were described for the commercial red shrimps and the non-commercial species for depths between 500 and $700 \mathrm{~m}$ in the Eastern Ioninan Sea (Mytilineou et al. 2006), where also the contribution of the a)

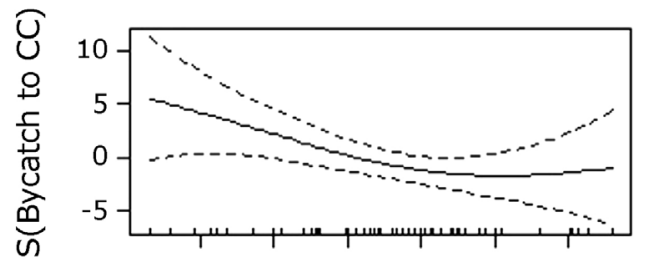

c)

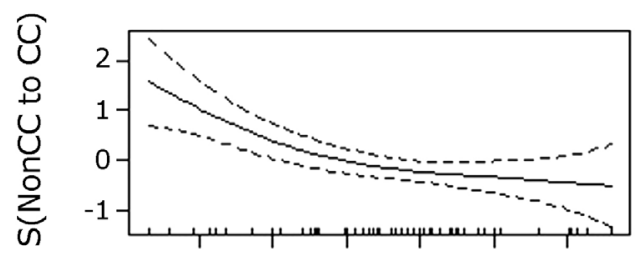

e)

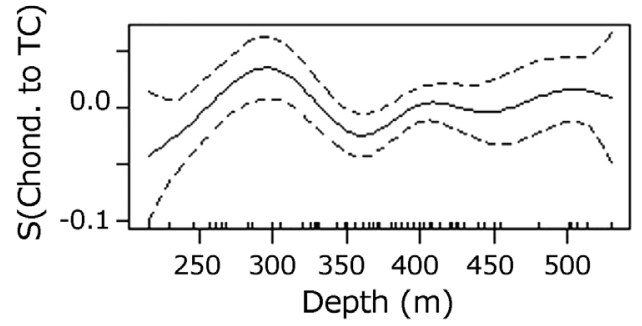

b)

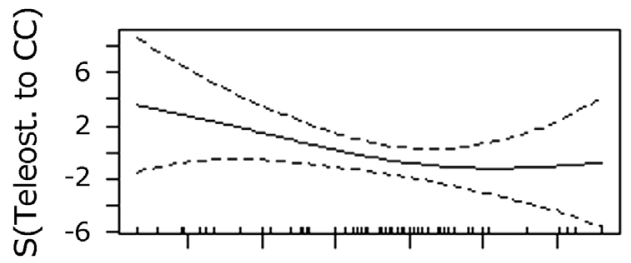

d)

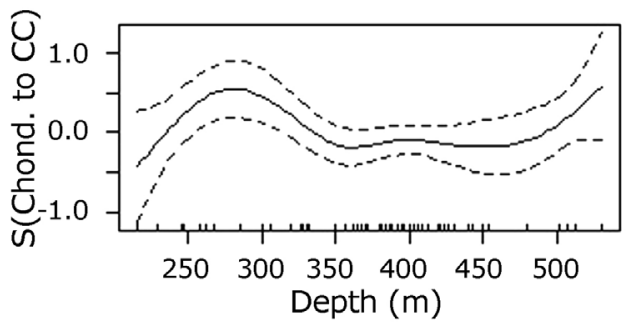

Figure 4. Trend of each catch composition index versus depth: a) By-catch to CC; b) Teleosteans to CC; c) NonCC to CC; d) Chondrichthyes to CC and e) Chondrichthyes to TC / Tendencia de cada índice de composición de captura versus la profundidad: a) By-catch a CC; b) Teleósteos a CC; c) NoCC a CC; d) Condrictios a CC y e) Condrictios a TC 
molluscs was negligible, ranging between $0.1 \%$ and $1 \%$ of the total catch. Our results included the shrimp A. foliacea, the fish C. agassizii and the shark C. granulosus between the most important species, in terms of weight and number of individuals. The contribution of these species in the studied area agrees with the catch composition of the unmarketable fish present in the discards from the red shrimp A. foliacea in the western Mediterranean (Moranta et. al. 2000, Mytilineou 2006), especially in relation to the importance of the genera Centrophorus, C. uyato and Etmopterus, $E$. spinax. The contribution of the latter groups was also described for the Brazilian deep-sea trawling fisheries which includes as the most important species the deepwater sharks (Etmopteridae Etmopterus lucifer 1617 individuals) and the skate (Rajidae Gurgesiella dorsalifera 688 individuals) between the elasmobranch discards for the area (Pérez et al. 2013). The most important finfish belongs to two families: Neoscopelidae (Myctophiformes) and Macruridae (Gadiformes) and between the eight principal components of the deep-water shrimp fisheries appear the finfish Coelorinchus marinii and the red shrimp A. foliacea (Pérez et al. 2013). The abundance of the red shrimp $A$. foliacea in the Colombian Caribbean Sea increases with depth (Paramo \& Saint-Paul 2012c); higher abundances were reported for deeper strata (400500 and $>500 \mathrm{~m}$ ). These results agree with the maximum abundances reported for this species between 500 and 700 $\mathrm{m}$ worldwide (Mytilineou et al. 2006, Papaconstantinou \& Kapiris 2001, Ragonesse et al. 2001, Politou et al. 2003, 2004). In many countries A. foliacea is a commercially valuable crustacean; however, unregulated trawling fishery has reduced its biomass into critical levels (Cau et al. 2002, Mytilineou et al. 2006, Pérez et al. 2013). For the Colombian Caribbean Sea $A$. foliacea reveals a potential for a new fishery (354.8 ind. $\mathrm{km}^{-2}$ ) (Paramo \& Saint-Paul 2012c) in comparison to the median densities calculated for this species in the Brazilian shrimp fishing during 20052006 (100-200 ind. $\mathrm{km}^{-2}$ ), showing the most aggregately distributional pattern in the fishing area (Pérez et al. 2013). There is a clear evidence that fish groups from the Colombian Caribbean Sea appears to coexist with several areas of high concentration of commercially important deep-sea crustaceans (i.e., Aristaeomorpha foliacea, Pleoticus robustus, Penaeopsis serrata, Metanephrops binghami) described in recent studies (Paramo et al. 2011, Paramo \& Saint-Paul 2012a,b,c). The abundance of the mentioned crustacean species in deeper bottoms in the Colombian Caribbean could be explained due to benthic or benthopelagic distributional pattern exhibited by larger individuals (Aguzzi et al. 2007). Large size crustaceans do not migrate off bottom, but follow sloping seabed occupying upper slope (Aguzzi \& Compani 2010, MacIsaac et al. 2014). The maximum biomass values were obtained in the present study at around depths $>500 \mathrm{~m}$, could reflect an individual size increment by depth (Paramo \& Saint-Paul 2012a,b,c), rather than an overall increase in number. The presence of larger individuals in deeper waters is known as the bigger-deeper phenomenon (Haedrich \& Rowe 1977, Pollini et al. 1979), which is explained as an ontogenic migration of individuals to deeper water (Stefanescu et al. 1992). This a common characteristic of deep-sea organisms where the adults benefit from a reduced metabolic rate and the life expectancy is increased due to the low habitat temperatures at deeper waters (Love 1970, 1980; Cushing 1983). Consequently, a bigger-deeper trend seems to appear on upper slope with middle and large-size species and individuals could reach their highest abundance in deeper waters and replace smaller species that dominate at shallower depths (Moranta et al. 1998). Nevertheless, future studies using size-based community metrics such as size spectrum should aim in that direction. The changes of the faunistic composition between different megafaunal assemblages are due to the substitution of the dominant and subdominant species, throughout the depth gradient, by a continuous faunistic turnover (Hecker 1990). The zonation pattern obtained in our study could be associated with different bathymetric strata and revealed higher teleost abundances between 200-300 m depth, and crustaceans dominating over the $400 \mathrm{~m}$ depth strata. Between the crustaceans, P. serrata was the most abundant (578.7 ind. $\mathrm{km}^{-2}$ ) species caught at median depths (200-500 m) and was subdominant in deeper waters $(>500 \mathrm{~m})$ where is replaced by $P$. robustus. In addition, depth seems to control on the vertical zonation of all marine biota including the demersal crustaceans for the Colombian Caribbean Sea (Moranta et al. 1998, Paramo et al. 2012, MacIsaac et al. 2014). In addition to depth, is noticeable that the trophic relationships between the two dominant groups (crustaceans and teleosts) in the studied area would probably be based on a competitive exclusion due to the exploitation of similar food resources rather than on predator/prey relationships, as was described in different deep-sea communities (Cartes et al. 2001). Since, some of the mentioned fish species prey over supra-benthos but also infauna or planktonic preys, the abundance distribution pattern of fish and crustacean suggests the contribution of important sources of organic matter form the phytodetritus of the pelagic zone exported from upwelling productive areas to the deep-sea ecosystems (Rice et al. 1986). Furthemore, higher abundances of fish and crustaceans in the Colombian Caribbean seems to be modulated by the local oceanography specifically by the seasonal upwelling (Paramo et al. 2009), and river continental discharges (Manjarrés 2011) with effects on deeper horizons by export flux from surface to seafloor (Bakun 1996, Paramo \& Saint-Paul 2010). 
Fisheries continue to move towards deeper waters around the world (Simpfendorfer \& Kyne 2009) but most of them are highly susceptible to overfishing (Relini \& Orsi-Reliniv 1987, Stevens et al. 2000, Queirolo et al. 2011). Therefore, the virgin populations of the Colombian Caribbean must consider an ecosystem-based management and maintain their biomass sustainably with very low exploitation rates. Intensive exploitation of the fishing resources over the past decades, mainly on the continental shelves, has led to the progressively declining catches of many fish and crustacean stocks (Pauly et al. 2003). In response, new fishing areas in deeper and deeper waters are being developed, taking advantage of recent advances in capture technologies (Pauly et al. 2003). Nevertheless, deep-sea ecosystems and fisheries are not considered highly productive and are especially vulnerable to over-exploitation due to the life-history characteristics of deep-sea species, including extreme longevity, slow growth rate, late maturity and low fecundity (Morato et al. 2006, Follesa et al. 2011). The potential effects of the threats on deep-sea resources include the extensive restructuring of entire ecosystems, changes in the geographical ranges of many species, large-scale elimination of taxa, and a decline in biodiversity at all scales (Robison 2009). For this reason, the stocks of deep waters tend to collapse much more rapidly, and their recuperation is slower, in contrast with the shallow environments (Roberts 2002). Among the results of anthropogenic impact which affect these ecosystems are: i) the removal of predators by fishing and the removal of habitat-forming species (such as gorgonians and stony corals), ii) the modification of the food webs among species and as a response to the allochthonous contribution of the by-catch which is taken advantage of by various groups, iii) the accumulation of heavy metals and toxins, and iv) global climate changes that alter the quantity and quality of food that reaches the deep waters (WWF/IUCN 2004). Therefore, the sustainable use of new fisheries should include the life history of the target species, their ecology and bio-economic potential, as well as of the associated biodiversity in deep-sea ecosystems (FAO 2003, Munro 2011). Therefore, we suggest a deep and detailed analysis about the potential and irreversible impact of the fishing footprint over slope benthic environments in the Colombian Caribbean, before considering any kind of trawl fishery.

The implementation of spatial management, with zoning for different kinds of fishing activity and use of seasonal or temporary closures is one important measure that should be included in the ecosystem-based management of the deepsea and resources in the Colombian Caribbean. This can be a useful tool for reducing discard rates and controlling effort exerted. Spatial management measures must be underpinned by a good knowledge of the biology, spatial distribution and abundance of both resource species and other species impacted by fisheries, including protected species (Bellido et al. 2011). Marine protected areas (MPA) have emerged as a tool for marine conservation and fisheries management following an ecosystem-based approach (Worm et al. 2006, Fraser et al. 2009, Paramo et al. 2009, Jackson \& Jacquet 2011). The ecosystem-based management of the deep-sea and resources should be based on an ecosystem approach, that considers population dynamics and structure and function of the ecosystem, the optimum allocation of catches and effort, protection of nursery and spawning areas, the development of monitoring strategies and the care of ecosystems through the implementation of MPA. This holistic approach will allow an appropriate level of biodiversity and the habitat quality to be maintained, while accomplish sustainable fisheries.

In conclusion, experimental trawling catches from the Colombian Caribbean Sea were characterized by the dominance of finfish and crustaceans in all depth strata. Some of the dominant groups described for the Colombian Caribbean Sea were also important components of deepsea assemblages in different regions worldwide. Finally, this study presents baseline information needed for understanding the potential ecosystem effects of trawling fishery and the implementation of an ecosystem approach to deep-sea fisheries management in the Colombian Caribbean Sea.

\section{ACKNOWLeDgments}

This work was sponsored by COLCIENCIAS grant number 1117-452-21288, Universidad del Magdalena (UMagdalena). Scientific fishing was approved by the Instituto Colombiano de Desarrollo Rural (INCODER) through the Subgerencia de Pesca y Acuicultura. This is a contribution of the research groups Ciencia y Tecnología Pesquera Tropical (Tropical Fisheries Science and Technology-CITEPT, UMagdalena). We also thank the crew of vessel "Tee Claude" and Captain José Guillem and members of research group CITEPT that participated in the laboratory and research survey.

\section{LITERATURE CITED}

Agenbag J, A Richardson, H Demarcq, P Freón, S Weeks \& F Shillington. 2003. Estimating environmental preferences of South African pelagic fish species using catch size and remote sensing data. Progress in Oceanography 59: 275-300.

Aguzzi J \& J Company. 2010. Chronobiology off deep-water decapod crustaceans on continental margins. Advances in Marine Biology 58: 155-225.

Aguzzi J, J Company, P Abelló \& J García. 2007. Ontogenetic changes in vertical migratory rhythms of benthopelagic shrimps Pasiphaea multidentata and P. sivado. Marine Ecology Progress Series 335: 167-174. 
Álvarez-León R \& I Rey-Carrasco. 2003. Fauna extraída en la exploración del barco M/N "Vikheim" al noroeste del Caribe colombiano. Revista de Biología Tropical 51(2): 551-554.

Arana P, JA Alvarez-Pérez \& PR Pezzuto. 2009. Deep-sea fisheries off Latin America: an introduction. Latin American Journal of Aquatic Research 37: 281-284.

Bakun A. 1996. Patterns in the ocean: ocean processes and marine population dynamics, $346 \mathrm{pp}$. University of California Sea Grant, UCSD, Centro de Investigaciones Biológicas de Noroeste, La Paz.

Bellido JM, M Begoña-Santos, M Grazia-Pennino, X Valeiras \& GJ Pierce. 2011. Fishery discards and bycatch: solutions for an ecosystem approach to fisheries management? Hydrobiologia 670: 317-333.

Bianchi G, H Gislason, K Graham, L Hill, X Jin, K Koranteng, S Manickchand-Heileman, I Payá, K Sainsburry, F Sanchez \& K Zwanenburg. 2000. Impact of fishing on size composition and diversity of demersal fish communities. ICES Journal of Marine Science 57: 558-571.

Burnham K \& D Anderson. 2002. Model selection and multimodeli-Inference: A practical information-theoretic approach, 488 pp. Springer-Verlag, New York.

Can M, Y Mazlum, A Demirci \& M Aktas. 2004. The catch composition and Catch per Unit of Swept Area (CPUE) of penaeid shrimps in the bottom trawls from Iskenderun Bay, Turkey. Turkey Journal of Fisheries and Aquatic Science 4: 87-91.

Cartes JE, F Maynou, B Morales-Nin, E Massutí \& J Moranta. 2001. Trophic structure of a bathyal benthopelagic boundary layer community south of the Balearic Island (southwestern Mediterranean). Marine Ecology Progress Series 215: 23-35.

Cavanagh R \& PM Kyne. 2006. The conservation status of deep-sea chondrichthyans fishes. In: Shotton R (ed). Deep Sea 2003: Conference on the governance and management of deep-sea fisheries. Part 2: Conference poster papers and workshop papers. FAO Fisheries Proceeding 3/2: 366-378.

Cau A, A Carbonell, M Follesa, A Mannini, G Norrito, L Orsi-Relini, CY Politou, S Ragonese \& P Rinelli. 2002. MEDITS-based information on the deep-water red shrimps Aristaeomorpha foliacea and Aristeus antennatus (Crustacea: Decapoda: Aristeidae). Scientia Marina 66(2): 103-124.

Cushing DH. 1983. Climate and fisheries, 273 pp. Academic Press, London.

Díaz L, A Roa, C García, A Acero \& G Navas. 2000. Lengthweight relationships of demersal fishes from the upper continental slope off Colombia. Naga 23(3): 23-25.

D'Onghia G, CY Politou, A Bozzano, D Lloris, G Rotllant, L Sion \& F Mastrototaro. 2004. Deep-water fish assemblages in the Mediterranean Sea. Scientia Marina 68(3): 87-99.

FAO. 2003. Fisheries management 2 . The ecosystem approach to fisheries. FAO Technical Guidelines for Responsible Fisheries No 4, Suppl. 2: 1-112. Food and Agricultural Organization of the United Nations, Rome
Follesa M, C Porcu, S Cabiddu, A Mulas, A Deiana \& A Cau. 2011. Deep-water fish assemblages in the central-eastern Mediterranean (south Sardinian deep-waters). Journal of Applied Ichthyology 27: 129-135.

Fraser HM, SPR Greenstreet \& GJ Piet. 2009. Selecting MPAs to conserve groundfish biodiversity: the consequences of failing to account for catchability in survey trawls. ICES Journal of Marine Science 66: 82-89.

Gotelli N \& A Ellison. 2004. A primer of ecological statistics, 492 pp. Sinauer Associates Sunderland, Massachusetts.

Gunderson D. 1993. Surveys of fisheries resources, 248 pp. Wiley, New York.

Haedrich RL \& GT Rowe. 1977. Megafaunal biomass in the deep-sea. Nature 269: 141-142.

Hastie T \& R Tibshirani. 1990. Generalized additive models, 352 pp. Chapman and Hall, London.

Hecker B. 1990. Variation in megafaunal assemblages on the continental margin south of New England. Deep-Sea Research 37: 35-57.

Jackson J \& J Jacquet. 2011. The shifting baselines syndrome: perception, deception, and the future of our oceans. In: Christensen V \& J Maclean (eds). Ecosystem approaches to fisheries, pp. 128-141. Cambridge, New York.

Kelleher K. 2005. Discards in the world's marine fisheries. An update, 131 pp. FAO Fisheries Technical Paper 470: 1-131.

King M. 2007. Fisheries biology, assessment and management, 400 pp. Blackwell Publishing, Oxford.

Labropoulou M \& C Papaconstantinou. 2005. Effect of fishing on community structure of demersal fish assemblages. Belgian Journal of Zoology 135(2): 191-197.

Love RM. 1970. The chemical biology of fishes, 547 pp. Academic Press, London.

Love RM. 1980. The chemical biology of fishes. Volume 2: Advances 1968-1977. With a supplementary key to the chemical literature, 943 pp. Academic Press, New York

MacIsaac K, T Kenchington, E Kenchington \& M Best. 2014. The summer assemblage of large pelagic Crustacea in the Gully submarine canyon: major patterns. Deep-Sea Research II 104: 51-66.

Manjarrés L. 2011. Ensamblajes de peces demersales del Caribe colombiano: Patrones espacio- temporales y relación con variables ambientales y pesqueras. Ph.D. Thesis, Universidad de Cadiz, Cadiz, 220 pp.

Moranta J, C Stefanescu, E Massutí, B Morales-Nin \& D Lloris. 1998. Fish community structure and depth-related trends on the continental slope of the Balearic Islands (Algerian basin, western Mediterranean). Marine Ecology Progress Series 171: 247-259.

Moranta J, E Massutí \& B Morales-Nin. 2000. Fish catch composition of the deep-sea decapod crustacean fisheries in the Balearic Islands (western Mediterranean). Fisheries Research 45: 253-264.

Morato T, R Watson, TJ Pitcher \& D Pauly. 2006. Fishing down the deep. Fish and Fisheries 7: 24-34. 
Munro JL. 2011. Assessment of exploited stocks of tropical fishes: an overview. In: Christensen V \& J Maclean (eds). Ecosystem approaches to fisheries, pp. 145-170. Cambridge, New York.

Mytilineou Ch, S Kavadas, CY Politou, K Kapiris, A Tursi \& P Maiorano. 2006. Catch composition on red shrimps' (Aristaeomorpha foliacea and Aristeus antennatus) grounds in the Eastern Ionian Sea. Hydrobiologia 557: 155-160.

Paighambari SY \& D Moslem. 2012. The by-catch composition of shrimp trawl fisheries in Bushehr coastal waters, the Northern Persian Gulf. Journal of the Persian Gulf Marine Science 3(7): 27-36.

Papaconstantinou C \& K Kapiris. 2001. The biology of the blue-and-red shrimp (Aristeus antennatus) on an unexploited fishing ground in the Greek Ionian Sea. Aquatic Living Resources 14: 303-312.

Paramo J \& U Saint-Paul. 2010. Morphological differentiation of southern pink shrimp Farfantepenaeus notialis in Colombian Caribbean Sea. Aquatic Living Resources 23(1): 95-101.

Paramo J \& U Saint-Paul. 2012a. Spatial structure of the pink speckled deep-sea shrimp Penaeopsis serrata (Bate, 1881) (Decapoda, Penaeidae) during November-December 2009 in the Colombian Caribbean Sea. Crustaceana 85(1): 103-116.

Paramo J \& U Saint-Paul. 2012b. Spatial structure of deepsea lobster (Metanephrops binghami) in the Colombian Caribbean Sea. Helgoland Marine Research 66: 25-31.

Paramo J \& U Saint-Paul. 2012c. Deep-sea shrimps Aristaeomorpha foliacea and Pleoticus robustus (Crustacea: Penaeoidea) in the Colombian Caribbean Sea as a new potential fishing resource. Journal of the Marine Biological Association of the United Kingdom 92(4): 811-818.

Paramo J, L Guillot, S Benavides, A Rodríguez \& C Sánchez. 2009. Aspectos poblacionales y ecológicos de peces demersales de la zona norte del Caribe colombiano en relación con el hábitat: una herramienta para identificar Áreas Marinas Protegidas (AMPs) para el manejo pesquero. Caldasia 31: 123-144.

Paramo J, U Saint-Paul, F Moreno, M Pacheco, M Almanza, G Rodríguez, N Ardila, B Effer, C Borda, C Barreto \& H González. 2011. Crustáceos de profundidad en el Caribe colombiano como nuevo recurso pesquero, $22 \mathrm{pp}$. Informe Final, COLCIENCIAS-INCODER- UNIMAGDALENAZMT-CITEPT, Santa Marta.

Paramo J, M Wolff \& U Saint-Paul. 2012. Deep-sea fish assemblages in the Colombian Caribbean Sea. Fisheries Research 126: 87-89.

Pauly D, J Alder, E Bennett, V Christensen, P Tyedmers \& R Watson. 2003. The future for fisheries. Science 21: 1359-1361.

Pérez J, N Pereira, D Pereira \& R Schroeder. 2013. Composition and diversity patterns of megafauna discards in the deep-water shrimp trawl fishery off Brazil. Journal of Fish Biology 83: 804-825.

Polanco A, A Acero \& M Garrido-Linares. 2010. Aportes a la biodiversidad íctica del Caribe colombiano. En: Biodiversidad del margen continental del Caribe colombiano. Serie de Publicaciones Especiales, INVEMAR 20: 317-354.
Politou CY, A Tursy, S Kvdas, Ch Mytilineou, G Lembo \& R Carlucci. 2003. Fisheries resources in the deep waters on the Eastern Mediterranean (Greek Ionian Sea). Journal of Northwest Atlantic Fishery Science 31: 35-46.

Politou CY, K Kapiris, P Maiorano, F Capezzuto \& J Dokos. 2004. Deep-water biology of Aristaeomorpha foliacea (Risso, 1827) (Crustacea: Decapoda: Aristeidae) in the Mediterranean Sea. Scientia Marina 68(3): 129-139.

Pollini P, RL Haedrich, G Rowe \& CH Clifford. 1979. The size-depth relationship in deep ocean animals. Hydrobiologia 64(1): 39-46.

Queirolo D, K Erzini, C Hurtado, E Gaete \& MC Soriguer. 2011. Species composition and by- catch of a new crustacean trawl in Chile. Fisheries Research 110: 149-159.

Ragonesse S, M Zagra, L Di Stefano \& ML Bianchini. 2001. Effect of codend mesh size on the performance of the deepwater bottom trawl used in the red shrimp fishery in the Strait of Sicily (Mediterranean Sea). Hydrobiologia 449: 279-291.

Relini G \& L Orsi-Reliniv. 1987. The decline of red shrimps stocks in the Gulf of Genova. Scientia Marina 51(1): 254260.

Rice A, D Billett, J Fry, A John, R Lampitt, R Mantoura \& R Morris. 1986. Seasonal deposition of phytodetritus to the deep-sea floor. Proceedings of the Royal Society of Edinburgh, Section B: Biology 88B: 265-279.

Roa-Varón A, L Saavedra-Díaz, A Acero \& L Mejía \& G Navas. 2003. Nuevos registros de peces óseos para el Caribe colombiano de los órdenes Beryciformes, Zeiformes, Perciformes y Tetraodontiformes. Boletín de Investigaciones Marinas y Costeras 32: 3-24.

Roberts C. 2002. Deep impact: the rising toll of fishing in the deep sea. Trends in Ecology and Evolution 17(5): 242-245.

Robison BH. 2009. Conservation of deep pelagic biodiversity. Conservation Biology 23: 847-858.

Saavedra-Díaz L, A Roa-Varón, A Acero \& L Mejía. 2004. Nuevos registros ícticos en el talud superior del Caribe Colombiano (Órdenes Albuliformes, Anguilliformes, Osmeriformes, Stomiiformes, Ateleopodiformes, Aulopiformes y Pleuronectiformes). Boletín de Investigaciones Marinas y Costeras 33: 181-207.

Simpfendorfer CA \& PM Kyne. 2009. Limited potential to recover from overfishing raises concerns for deep-sea sharks, rays and chimaeras. Environmental Conservation 36(2): 97-103.

Sparre P \& C Venema. 1995. Introducción a la evaluación de recursos pesqueros tropicales, Parte 1 Manual. FAO Fisheries Technical Paper 306/1, Rev.1: 1-420.

Stefanescu C, J Rucabado \& D Lloris. 1992. Depth-size trends in western Mediterranean demersal deep-sea fishes. Marine Ecology Progress Series 81: 205-213.

Stevens J, R Bonfil, N Dulvy \& P Walker. 2000. The effects of fishing on sharks, rays and chimaeras (Chondrichthyans) and the implications for marine ecosystems. ICES Journal of Marine Science 57: 476-494. 
Wehrtmann IS \& S Echeverría. 2007. Crustacean fauna (Stomatopoda: Decapoda) associated with the deepwater fishery of Heterocarpus vicarius (Decapoda: Pandalidae) along the Pacific coast of Costa Rica. Revista de Biología Tropical 55(1): 121-130.

Wehrtmann IS, PM Arana, E Barriga, A Gracia \& PR Pezzuto. 2012. Deepwater shrimp fisheries in Latin America: a review. Latin American Journal of Aquatic Research 40: 497-535.

Worm B, EB Barbier, N Beaumont, JE Duffy, C Folke, BS Halpern, JBC Jackson, HK Lotze, F Micheli, SR Palumbi, E Sala, KA Selkoe, JJ Stachowicz \& R Watson. 2006. Impacts of biodiversity loss on ocean ecosystem services. Science 314(3): 787-790.
WWF/IUCN. 2004. The Mediterranean deep-sea ecosystems: an overview of their diversity, structure, functioning and anthropogenic impacts, with a proposal for conservation, 66 pp. IUCN Centre for Mediterranean Cooperation/WWF Mediterranean Programme, Málaga/Rome.

Zar J. 2009. Biostatistical analysis, 960 pp. Prentice Hall, Englewood Cliffs.

Received 27 July 2018 and accepted 24 June 2019

Editor: Claudia Bustos D. / Editor partner: Javier Díaz Ochoa 